\title{
TOMASZ PAWLIKOWSKI
}

\section{SUÁREZ I ANALOGIA W ŚWIETLE NOWYCH BADAŃ}

Kazimierz Gryżenia SDB. Analogia w scholastyce nowożytnej. Studium z metafizyki Franciszka Suáreza. Lublin: Polskie Towarzystwo Tomasza z Akwinu, 2019, ss. 298. ISBN: 978-83-65792-18-1.

DOI: http://doi.org/10.18290/rf21692-24

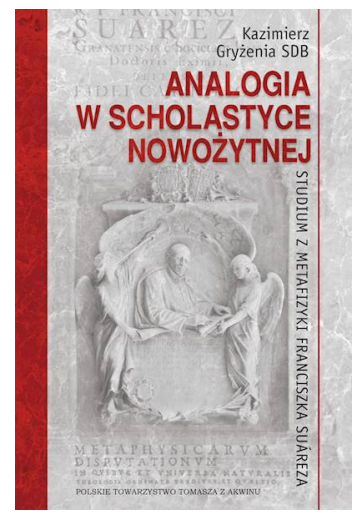

1. Struktura monografi. Książka składa się ze Wstępu (s. 5-18), czterech rozdziałów (s. 19-247), Zakończenia (s. 249257), streszczenia w języku angielskim — Summary (s. 259267), Indeksu osobowego (s. 269-273) i Indeksu przedmiotowego (s. 275-279), Bibliografii (281-294), spisu treści w języku angielskim (Contents - s. 295-296) i polskim (s. 297-298).

Rozdział 1, zatytułowany „Sposoby orzekania o bycie. Między wieloznacznością a jednoznacznością", jest najkrótszy (s. 19-59) i wydaje się poglądowym wprowadzeniem do problematyki analogii. Rozdział 2, „Rodzaje analogii” (s. 61-109), i Rozdział 3, „Koncepcja bytu jako przedmiotu metafizyki” (s. 111-200), stanowią bez wątpienia rdzeń monografii. W nich zostały sformułowane najistotniejsze ustalenia. Rozdział 4, „Zastosowanie analogii do poznania istnienia i natury Boga" (s. 201-247), owe ustalenia wykorzystuje i wyprowadza z nich konsekwencje dla rozważań szczegółowego zagadnienia, którego przybliżenie dopełnia całości obrazu podjętej w pracy problematyki.

Struktura pracy zdaje się wynikać z uwarunkowań omawianego przedmiotu. Autor wskazuje zresztą już we Wstępie na kwestię bytu i analogii jako na zagadnienia najistotniejsze dla całości prezentowanych w pracy rozważań. Sam za „najbardziej zasadniczy dla problemu analogii i tematu pracy" uznaje Rozdział 3 i omawianą tam koncepcję bytu jako przedmiotu metafizyki (s. 16-18). Ze względu na rzeczywiste potrzeby, podyktowane meritum przedstawianej problematyki, rozmiary poszczególnych rozdziałów oraz ich ilość wydają się optymalne. Zachowanie formalnych proporcji w liczbie stron między nimi wymagałoby zaś zmiany koncepcji w naświetleniu całości podejmowanego problemu.

Dr hab. Tomasz Pawlikowski - Biblioteka Publiczna m.st. Warszawy - Biblioteka Główna Województwa Mazowieckiego; adres do korespondencji: ul. Koszykowa 26/28, 00-950 Warszawa; e-mail: pawlikowski.tomasz-1970@wp.pl; ORCID: https://orcid.org/0000-0003-0618-611X. 
Cennym dodatkiem są indeksy: osobowy i rzeczowy. Ten ostatni wydaje się dość obszerny i strukturalnie rozbudowany, jak na stosunkowo krótką publikację o charakterze monograficznym. Bardzo dobry jest bez wątpienia układ Bibliografii, odróżniający: Źródło pierwszorzędne, Źródła drugorzędne, Opracowania i Literaturę pomocniczą. Mimo dysproporcji między pierwszym jej działem, w którym wskazane jest tylko główne dzieło F. Suáreza, a drugim z działów, obejmującym wykaz ośmiu wykorzystanych dzieł innych historycznych autorów, wyszczególnienie Disputaciones metafisicas, wydanych w wersji łacińskiej i hiszpańskiej, w siedmiu tomach w Madrycie, w latach 1960-1966 (łaciński tytuł Disputationes metaphysicae), wydaje się w pełni uzasadnione metodycznie. Zawiera się tutaj bowiem tekst podstawowy dla przedstawionych w omawianej monografii badań historyczno-filozoficznych.

2. Przegląd treści geównych części monografit. Pisząc o głównych częściach monografii, mam w tym przypadku na uwadze Wstęp, cztery rozdziały wyznaczające tzw. korpus, oraz Zakończenie. W nich zawiera się bowiem cały wykład podjętej przez autora problematyki i uzyskane przezeń ustalenia. Wstęp wskazuje nie tylko układ treści, co zostało potraktowane akurat dość krótko (s. 17-18), ale od razu wprowadza czytelnika w kontekst historycznego kształtowania się teorii analogii i badań nad nią podejmowanych. Rangę przedstawianego problemu naświetla już pierwsze zdanie, będące przekładem wypowiedzi Tomasza de Vio, czyli Kardynała Kajetana: „Znajomość analogii jest tak konieczna, że bez niej nikt nie może uprawiać metafizyki, a i w innych naukach z jej nieznajomości płynie wiele błędów" (s. 5). Zaczynając od tego cytatu, K. Gryżenia ukazuje na kolejnych stronach, jak doszło do ponownego uświadomienia sobie wagi problemu analogii przez czołowych przedstawicieli współczesnej filozofii realistycznej w środowisku lubelskim (M. A. Krąpiec, P. Jaroszyński, A. Maryniarczyk), kontynuujących kierunek wyznaczony przez É. Gilsona (s. 5-7). Naświetla także kontekst historyczny, w którym F. Suárez tworzył Disputationes metaphysicae (1597). Wyznaczały go poglądy Piotra Fonseki, prace nad jezuickim Ratio studiorum (1599), regulującym system edukacyjny zakonu, reakcja na idee renesansu, spierające się w scholastyce nurty szkotyzmu i tomizmu, zalecenie Piusa V, by na katolickich uczelniach wykładano naukę św. Tomasza z Akwinu, ogłoszonego przez tegoż papieża w 1567 r. Doktorem Kościoła, a wcześniej przez Ignacego Loyolę Doktorem zakonu (s. 8-12). K. Gryżenia zaznacza, że dzieło F. Suáreza stanowiło przełom w wykładaniu filozofii, stając się w XVII wieku podstawą programu nauczania na wszystkich uczelniach europejskich, także luterańskich i kalwińskich, nadto źródłem wiedzy o najważniejszych myślicielach przeszłości. Jego znaczenie stało się tak duże, iż obok szkoły tomistycznej (dominikańskiej) i szkotystycznej (franciszkańskiej), zaczęto wyróżniać szkołę suarezjańską (jezuicką). Dlatego można uznać, że doszło tu do oryginalnej syntezy filozoficznej (s. 8-9).

Wśród współczesnych badaczy metafizycznej doktryny F. Suáreza nie ma zgodności co do zasadniczego rysu jej charakteru. Zazwyczaj jedni akcentują obecne w niej elementy ,arystotelizmu tomistycznego” (s. 10), inni szkotystyczne (s. 11-12). 
K. Gryżenia proponuje rozstrzygnięcie narosłego w tej kwestii sporu w oparciu o analizę wykładu teorii analogii, gdyż ta łączy się z Tomaszową egzystencjalną koncepcją bytu, podczas gdy jej brak i jednoznaczność z esencjalną koncepcją bytu autorstwa Jana Dunsa Szkota (s. 13). Tu jednak pojawia się kolejna trudność, gdyż niektórzy badacze uważają, że proponowana przez F. Suáreza koncepcja analogii bytu sprowadza de facto analogię metafizyczną do jednoznaczności. Kluczowe wydaje się zatem ustalenie, czy przyjmowane przezeń pojęcie bytu jest analogiczne czy jednoznaczne i jaki status przyznaje on istnieniu bytu. Czy hiszpański scholastyk traktuje go jako akt (co przyjmuje tomizm) czy modalność istoty (co jest właściwe szkotyzmowi)? Przy tym - jak zaznacza K. Gryżenia — rozstrzygnięcie tych spornych kwestii nie jest wcale pewne, o czym świadczą liczne i niezakończone jednolitym ustaleniem prace, podejmowane przez poprzedników (s. 14-16). Argument odwołujący się do wielości dotychczasowych, nierozstrzygających ustaleń mógłby wydawać się słaby, niemniej część z nich wskazywała na niejasność i brak większego praktycznego znaczenia nauki F. Suáreza o analogii (s. 14-15). I trzeba przyznać, że gdyby okazało się to prawdą, okoliczność ta stanowiłaby obiektywną trudność dla dokonania ostatecznych rozstrzygnięć.

Rozdział 1 omawia sposoby orzekania o bycie, sprowadzające się do kwestii wieloznaczności, jednoznaczności i analogiczności nazw. Są to zagadnienia wprowadzające $\mathrm{w}$ zasadniczą problematykę monografii. Istotne znaczenie ma niewątpliwie punkt 3, poświęcony orzekaniu analogicznemu. Znajdujemy tutaj potwierdzenie, że F. Suárez przyjmował analogię jako pośredni sposób orzekania między jednoznacznością i wieloznacznością, oraz stosował ją w odnoszeniu nazwy „byt” do Boga i stworzenia, wykluczając w tym przypadku jej jednoznaczne rozumienie. Przychylił się przez to ku stanowisku tomistycznemu. $Z$ drugiej strony opowiedział się za bliską szkotyzmowi tezą, że jest jedna ratio entis (pojęcie bytu lub racja bytu), która odnosi się zarówno do Boga, jak i do stworzenia. Byt jako taki był zatem przez hiszpańskiego myśliciela rozumiany jednoznacznie. Różnicę stanowiło tylko to, że Bogu bytowość przysługuje istotnie a stworzeniu nie (s. 40-41, 45). Wbrew tomistom F. Suárez wydawał się twierdzić, że nazwa „byt” odnosi się w takim samym znaczeniu do substancji i do przypadłości. Wskazywał też, że przypadłość można zdefiniować bez odniesienia jej do substancji, której przysługuje, oraz że racja bytu jest uwzględniana $\mathrm{w}$ definicjach zarówno substancji, jak i przypadłości, bez względu na to, czy rozumie się ją analogicznie czy jednoznacznie. Także przy rozumieniu jednoznacznym nie byłby traktowany w definicji jako rodzaj. Jest to teza ewidentnie niezgodna ze stanowiskiem tomistów, którzy byt pojmowali jako przekraczający kategorie, ale nie dopuszczali jego jednoznacznego określenia. Ze wzmianki o możliwości jednoznacznego ujęcia bytu K. Gryżenia wyprowadził wniosek, że hiszpański myśliciel przyjął w konsekwencji koncepcję jednoznaczności transcendentalnej (przekraczającej zakresowo rodzaj), a więc szukał drogi pośredniej między doktrynami św. Tomasza i Dunsa Szkota (s. 47-51). 
Przy końcu rozdziału pojawia się zagadnienie warunków analogiczności orzekania. Są nimi: a) wspólna różnym rzeczom treść, którą można uchwycić w jednym pojęciu; b) pozostawanie tych rzeczy we wzajemnym stosunku zależności, czyli pierwszeństwa i wtórności. W opisach analogii bytowej Suárez nazywał go nierównością porządku lub istotowej zależności. Nazwa „byt” odnosi się zatem pierwszorzędnie do Boga, wtórnie zaś do stworzeń, pomimo jednej i tej samej treści (s. 51-54). Wątpliwości autora omawianej monografii budzi jednak to, że Suárez sprowadzał analogię proporcjonalności do analogii metaforycznej i wprowadzał koncepcję analogii atrybucji wewnętrznej, wcześniej niespotykanej. Wyraźnie krytyczne są przypuszczenia, że werbalnie akceptowana przez hiszpańskiego fillozofa analogia nazw pokrywa się istotnie z jednoznacznością lub jest jej bliska $\mathrm{z}$ uwagi na uznanie przezeń jednej ratio entis w przypadku Boga i stworzenia, substancji i przypadłości. Nie do przyjęcia wydaje się K. Gryżeni również koncepcja, że nazwę „byt”, a także inne, można rozumieć jednoznacznie lub wieloznacznie, w zależności od aspektu, w jakim się je rozpatruje (s. 55-58). We wnioskach kończących rozdział pyta też, czy Suárez nie popada w sprzeczność, gdyby okazało się, że z jednej strony utożsamił jednoznaczność transcendentalną z analogią a $z$ drugiej strony wykluczył w przypadku tej jednoznaczności przyjmowanie przez poszczególne byty porządku pierwszeństwa i wtórności (s. 58-59).

Rozdział 2 autor zaczyna od stwierdzenia, że F. Suárez poprzez opowiedzenie się za analogią wpisuje się w ramy arystotelizmu tomistycznego. Wstępnie rozpatruje zarówno analogię proporcjonalności, preferowaną przez św. Tomasza i Kajetana, jak i analogię atrybucji, za którą opowiedzieli się Franciszek Sylwester z Ferrary i Piotr Fonseka, łącząc ją jednak z poprzednią. Sprowadzając analogię proporcjonalności do analogii metafory i uznając ją za nieprzydatną dla metafizyki, Suárez przyją ostatecznie analogię atrybucji. Tej pierwszej zarzucał bowiem, że opiera się na przenośni i zbliża do wieloznaczności (s. 61-73, 79). Zasadniczą zmianą wobec tradycji było wprowadzenie przezeń do filozofii bytu analogii atrybucji wewnętrznej. Według założeń, uwzględnia ona jednakowe realizowanie się wspólnej doskonałości (analogonu) we wszystkich jej nośnikach (analogatach), przy zachowaniu hierarchii pierwszeństwa i wtórności. Można było za jej pomocą wskazać więc analogat główny, z pełnym natężeniem wspólnej doskonałości, i analogaty wtóre, posiadające ją w niepełnym stopniu. Ponieważ przy zastosowaniu analogii proporcjonalności nie dawało się wyróżnić analogatu głównego, F. Sylwester z Ferrary i P. Fonseka łączyli ją z analogią atrybucji, która taki analogat uwzględniała. F. Suárez poszedł o krok dalej i uznał, że chodzi tu o jeden typ analogii, opartej o powiązanie analogatów z jej wewnętrznymi doskonałościami. Dlatego nazwał ją analogią wewnętrzną, w odróżnieniu od analogii atrybucji wskazującej na posiadanie przez różne rzeczy wspólnych doskonałości zewnętrznych. W ten sposób uzyskał narzędzie do orzekania nazwy „byt” o Bogu i stworzeniach, substancji i przypadłości (s. 79-86). Wyodrębniane w analogii atrybucji wewnętrznej wspólne pojęcie, obejmujące jedną treść, mogło pełnić rolę terminu średniego w sylogizmie (s. 81). 
Zdaniem K. Gryżeni takie pojęcie jest mimo wszystko jednoznaczne, nie analogiczne. Przez to sama koncepcja staje się niespójna, mieszając analogię i jednoznaczność w opisie bytu, lub w wyniku niezamierzonej konsekwencji sprowadza analogię atrybucji wewnętrznej do jednoznaczności (s. 102, 105-106). Problem wydaje się tkwić w rozumieniu przez F. Suáreza podstawowego dla jego metafizyki pojęcia bytu jako bytu. Autor monografii za Ludgerem Honnefelderem uznaje, że jest ono jednoznaczne i abstrakcyjne. Ujmując tę samą treść, nie uwzględnia faktycznie pierwszeństwa i wtórności analogatów (s. 102-103). Mimo wszystkich zastrzeżeń K. Gryżenia przestrzega przed uproszczonym interpretowaniem poglądów hiszpańskiego scholastyka (s.103). Wskazuje ponadto, że zdaniem M. A. Krąpca w dalszych rozważaniach Suárez łagodził swoje stanowisko, prawdopodobnie dostrzegając w nim zmierzanie w kierunku akceptacji jednoznacznego rozumienia bytu (s. 108).

Rozdział 3, poświęcony koncepcji bytu jako przedmiotu metafizyki, okazuje się zatem tym, w którym pojawiają się główne ustalenia dla całej monografii. Jej autor pisze zresztą wprost: „Suarezjańska teoria analogii zostanie więc potwierdzona lub podważona prezentowaną przez niego koncepcją bytu jako bytu, który jest przedmiotem metafizyki" (s. 111). Problemem staje się od razu to, czy hiszpański filozof ma tu na względzie byt realny. Wiele jego wypowiedzi wskazuje bowiem, że on, pisząc o bycie, odnosi się do treści abstrakcyjnej, istotowo spójnej i zrozumiałej, niesprzecznej wewnętrznie, ale zaledwie zdolnej do aktualnego istnienia. Przedmiotem jego metafizyki byłaby więc wyabstrahowana quidditas. Suárez sugeruje to swoją koncepcją pojęcia formalnego (conceptus formalis) i obiektywnego (conceptus obiectivus). Pierwsze ma charakter subiektywny, gdyż obejmuje to, co intelekt chwyta z rzeczywistości. Drugie jest treścią rzeczy, którą to treść intelekt byłby w stanie uchwycić poznawczo, gdyby działał optymalnie. Przedmiot metafizyki utożsamił się w tym rozumieniu z obiektywną treścią bytu, którą intelekt ujmuje niezależnie od jej realnego istnienia. Egzystencjalny element bytu został tym samym pominięty w określeniu przedmiotu metafizyki. Wskazanie na abstrakcyjność pojęcia bytu jeszcze bardziej oddala zaś całą koncepcję od metafizycznego realizmu (s. 112-121). Nie to jednak było zamiarem hiszpańskiego scholastyka. Dostrzegając różnicę między logicznym i metafizycznym aspektem pojęcia bytu, nie zgadzał się on na przeciwstawianie ich sobie, ale usilnie podkreślał ich związek (s. 126). Pomimo intencji zachowania stanowiska realistycznego, opowiedzenie się przez Suáreza za doskonałą jednością treści i abstrakcyjnością pojęcia bytu wydaje się nie zgadzać z przyjętym twierdzeniem o jego analogiczności (s. 128).

Egzystencjalny aspekt bytu wskazuje w tej koncepcji metafizycznej jego imiesłowowe rozumienie (ens ut participium), w którym akcentuje się, że jest on „istniejący" (existens). Zdaniem K. Gryżeni u Suáreza przeważa jednak aspekt esencjalny, wyrażany ujęciem bytu jako nazwy (ens ut nomen). Aspekt ten skupia się na realnej istocie, ale pomija jej istnienie. Kolejne wyjaśnienia nie rozwiązują rodzących się wątpliwości. Wobec obiektywnie uzasadnionych trudności, wśród 
badaczy pojawiły się $\mathrm{w}$ efekcie cztery zasadnicze interpretacje suarezjańskiego pojęcia bytu (s. 129-136).

Pierwszą interpretację, logiczną, przyjął m.in. É. Gilson i Jean-François Courtine, a u nas Marian Borzyszkowski, M. A. Krąpiec i Piotr Jaroszyński. Opiera się ona na dwu założeniach: a) istota realna jest niesprzeczna; b) ens i res są tożsame treściowo. Jeśli przyjmiemy, jak twierdzi Courtine, że nazwa res, czyli „rzecz”, wskazuje na prawdziwą i określoną $\mathrm{w}$ sobie istotę, $\mathrm{z}$ pominięciem jej odniesienia do istnienia, prowadzi to do zacierania się różnicy między bytem myślnym a realnym. Istota zaledwie niesprzeczna i dająca się ując intelektem staje się natomiast przedmiotem metafizyki (s. 136-142).

Drugą jest interpretacja aktualistyczna, sformułowana przez Mariusa Schneidera. Przyjmuje ona, że metafizyka bada rzeczywiste formy istniejących aktualnie rzeczy, a podstawą do utworzenia pojęcia bytu ,jest tylko i wyłącznie urzeczywistniona natura bytu" (s. 142-143). U nas podobnie rozumie suarezjańskie pojęcie bytu Stanisław Ziemiański (s. 143-144). Nie zgadza się z taką interpretacją Rolf Darge, wskazując, że możliwość nie jest przeciwieństwem bytu w sensie nominalnym, skoro Suárez przeciwstawia byt w możności (tu utożsamiony z możliwym) bytowi w znaczeniu partycypatywnym. Jego pojęcie bytu w sensie nominalnym obejmuje natomiast zarówno byt aktualny, jak i możliwy (s. 144-145).

Trzecią jest interpretacja realistyczna, podtrzymywana przez takich autorów, jak Hans Seigfried, Ludger Honnefelder i Jorge J. E. Garcia. Również jej R. Darge nie uznaje jednak za właściwą dla scharakteryzowania koncepcji Suáreza, uważając że nie da się w jego wersji metafizyki wyłączyć bytu możliwego z jej przedmiotu. To zaś wyłączenie miałaby wprowadzać właśnie interpretacja realistyczna. Dlatego, w oparciu o własne badania, niemiecki badacz scholastyki proponuje jeszcze jedno stanowisko (s. 145-148).

Właśnie owa czwarta interpretacja wydaje się, zdaniem K. Gryżeni, najpełniejsza i najbardziej przekonująca na tle pozostałych. Według niej przedmiot metafizyki suarezjańskiej nie pomija ani bytu w możności, ani w akcie. Nieuwzględnieniu istnienia w określeniu bytu jako bytu R. Darge przypisuje jedynie znaczenie metodyczne. Przy właściwym zrozumieniu tekstów F. Suáreza - jak twierdzi - okazuje się, że określenie to obejmuje oba aspekty obiektywnego pojęcia bytu: treściowy i egzystencjalny. To obiektywne pojęcie bytu kieruje badania ku konkretnym jednostkowym rzeczom i ma źródło oraz przyczynę w ich poznaniu. Nie wskazuje ich wprost, ale i nie pomija. Mimo dostrzegania przewagi interpretacji, którą sformułował niemiecki badacz, nad pozostałymi K. Gryżenia zaznacza, że liczni autorzy, w tym É. Gilson, M. A. Krąpiec i P. Jaroszyński, uznali tego typu ujęcie bytu za esencjalne. Wskazuje też, że R. Darge nie wyjaśnia, czym według Suáreza jest wspólna dla zróżnicowanej rzeczywistości jednostkowych bytów treść obiektywnego pojęcia bytu (s. 148-153).

W dalszym ciągu rozważań, mających na celu scharakteryzowanie suarezjańskiego pojęcia bytu $\mathrm{w}$ aspekcie jednoznaczności bądź analogiczności, autor omawianej 
monografii przywołał dość istotną historycznie uwagę, że to hiszpański jezuita rozbudził od nowa dyskusję na temat różnicy między istotą i istnieniem, rozważając trzy historyczne stanowiska w tej sprawie (s. 153-155). Pierwsze, związane z nurtem tomistycznym, głosiło różnicę realną między tymi dwoma elementami bytu. W skrajnej postaci, którą atakował i odrzucał hiszpański jezuita, stwierdzało ono nawet, że istnienie i istota różnią się jak dwie rzeczy (s. 155-166). Drugie stanowisko, właściwe szkotyzmowi, opowiadało się za różnicą modalną. Nazwa najwyraźniej nie wydawała mu się istotna, gdyż zakwalifikował do tu również koncepcje wskazujące na formalne powody odróżnienia istnienia od istoty $\mathrm{w}$ bytach stworzonych. F. Suárez zadeklarował co prawda odrzucenie różnicy modalnej między aktualną istotą i egzystencją, ale jego niektóre wypowiedzi nie w tej materii budzą wątpliwości. Wydaje się bowiem wyróżniać modalności bytowania i stopnie realności istoty, jakkolwiek formalnie opowiedział się za koncepcją różnicy myślnej (s. 166-171). Z opinii w tej sprawie warto przywołać wskazywane przez K. Gryżenię stanowisko É. Gilsona, który uważał, że istnienie nie może być pojęte w metafizyce Suáreza jako coś odrębnego od istoty i jako jej akt, lecz utożsamia się ono $\mathrm{z}$ istotą rozumianą $\mathrm{w}$ aspekcie, w którym charakteryzowana jest ona jako coś aktualnego (s. 175).

Autor omawianej monografii wskazuje na potrzebę uwagi i ostrożności przy lekturze tekstów hiszpańskiego jezuity, gdyż „stosowaną przez niego terminologię łatwo zinterpretować w sposób uproszczony lub tendencyjny" (s. 180). Za Stefanem Swieżawskim przypomina, że u progu XVII wieku język filozofii skomplikował się znacznie w stosunku do tego, którym operował św. Tomasz z Akwinu. W dodatku spór na temat istoty i istnienia odbywał się wówczas na płaszczyźnie esencjalizmu (s. 181). Skoncentrowanie dociekań metafizycznych na istocie i przemiany terminologiczne doprowadziły z kolei Suáreza na antypody podstawowych założeń Akwinaty oraz skierowały go na pozycje awicenniańsko-szkotystyczne (s. 185). Termin ,istota realna” w tej nowej metafizyce nie zawsze oznaczał istotę aktualnie istniejącą. Realność zaś trudno było określić w odniesieniu do istnienia. W takim kontekście historycznym i doktrynalnym pojęcie bytu straciło związek z realnym światem (s. 190-191).

Jak twierdzi K. Gryżenia, hiszpański scholastyk niemal powtórzył w efekcie doktrynę Dunsa Szkota w kwestii rozumienia bytu jako bytu, dążąc do uczynienia z metafizyki teorii naukowej zawierającej wiedzę pewną, konieczną i niepowątpiewalną. Włączenie przez św. Tomasza z Akwinu w zakres badań metafizycznych zagadnienia istnienia spowodowało problem metodologiczny i ontyczny. Pociągało bowiem za sobą konieczność uwzględnienia w ramach teorii naukowej związanych $\mathrm{z}$ istnieniem stanów jednostkowych, co wykraczało poza Arystotelesowy paradygmat nauki. Nie dało się także go pominąć, gdyż bez istnienia nie ma bytu. Dlatego, zdaniem autora omawianej monografii, dążąc do rozwiązania narosłych w efekcie aporii, Suárez zasadniczo sprowadził kwestię istnienia do kwestii istoty. Nie zanegował wprawdzie racji uwzględniania $\mathrm{w}$ badaniach metafizycznych samego istnienia, ale praktycznie tak je opisał, że tym samym zneutralizował potrzebę jego rozważania. 
Według suarezjańskiej metafizyki poznanie istnienia nie jest wszelako niezbędne dla poznania istoty rzeczy (s. 196, 198-199).

Rozdział 4 monografii porusza kwestię poglądów Suáreza na funkcję analogii w dowodzeniu istnienia i poznaniu natury Boga. Scharakteryzowany tutaj jednak został raczej kontekst doktrynalny, niekiedy dość szeroki, niż analizy hiszpańskiego scholastyka (s. 202-207, 219-222, 227-237). Nie przedstawił bowiem żadnych argumentów za istnieniem Stwórcy. Podważał przy tym poprawność głównej przesłanki dowodu „fizykalnego" (ex motu), twierdząc że niektóre ciała mogą poruszać się same z siebie, dzięki zawartej w nich formie lub mocy wewnętrznej (s. 207-208). Uznawał, że jedyną skuteczną drogą wykazania istnienia Boga jest odwołanie się do ustaleń metafizyki (s. 208). Twierdził zarazem, że żadna nauka nie dowodzi istnienia swego przedmiotu, włączając Boga $\mathrm{w}$ zakres przedmiotu filozofii bytu (s. 215). Suárez rozpatrywał zatem kwestie związane z naturą Boga Stwórcy jako bytu pierwszego, najważniejszego i najgodniejszego w kontekście najogólniejszego pojęcia metafizycznego, którym jest ratio entis, $\mathrm{w}$ ramach porządku wykładania, a nie dowodzenia (s. 210-211).

Kazimierz Gryżenia wskazuje, że sposób ujęcia tej problematyki przez hiszpańskiego filozofa wynika z podobnego jej pojmowania, jakie było wcześniej udziałem Dunsa Szkota (s. 218). Koncentrując się na wypracowaniu pojęcia bytu, którego treść odpowiadałaby treści każdego poszczególnego bytu, w tym bytu Boga, Suárez skierował się ku koncepcji ontologii badającej pojęcia, a nie realne byty (s. 237-247). Przyjęta przez niego koncepcja analogii atrybucji wewnętrznej wyjaśniała zależność stworzeń od Boga Stwórcy, ale nie dawała możliwości formułowania w oparciu o nią dowodów na Jego istnienie (s. 245). W Zakończeniu monografii, autor stwierdza, że w tej koncepcji dochodzi do połączenia jednoznacznego i analogicznego pojęcia bytu, a więc stanowiska szkotystycznego i tomistycznego (s. 252). Posuwa się również do stwierdzenia, że w metafizyce Suáreza sama analogia okazuje się „mało potrzebna" (s. 255).

Właściwe wydaje się w tym miejscu dodać, że na ocenie wyrażonej przez K. Gryżenię $\mathrm{w}$ stosunku do koncepcji analogii atrybucji wewnętrznej i jej przydatności dla wyjaśniania relacji między stworzeniem a Stwórcą niewątpliwie zaważyła teza M. A. Krąpca, że jedyną nadającą się do tej roli jest analogia transcendentalna proporcjonalności właściwej. Krytyka stanowiska suarezjańskiego ma zatem charakter zewnętrzny, wynikający z ustaleń egzystencjalnej i realistycznej metafizyki o rodowodzie tomistycznym, uprawianej w Lubelskiej Szkole Filozoficznej (s. 232-237). Autor omawianej monografii ewidentnie uznaje suarezjańskie określenie bytu jako bytu oraz koncepcję analogii atrybucji wewnętrznej za błędne. Mimo to dostrzega podobieństwo $\mathrm{w}$ strukturach analogii atrybucji wewnętrznej i analogii transcendentalnej. W obu przypadkach jest uwzględniana wewnętrzna proporcja między bytami stworzonymi (analogatami wtórymi) i ich doskonałościami (analogonami), a także zależność stworzeń od Stwórcy jako analogatu głównego (s. 236). Problem 
przesunięcia metafizyki Suáreza w kierunku pozycji późniejszej ontologii, wydaje się zatem wynikać w tej perspektywie przede wszystkim z określenia pojęcia bytu.

3. UWAGI KoŃCOWE. Padająca w Zakończeniu monografii teza o niewielkiej przydatności analogii w metafizyce suarezjańskiej wydaje się niezupełnie trafna wobec wcześniej przedstawionych, obszernych rozważań na jej temat, przedstawionych zwłaszcza w Rozdziale 2. Teza taka nie jest wszelako pozbawiona podstaw i współbrzmi $\mathrm{z}$ wielokrotnie pojawiającymi się $\mathrm{w}$ omawianej pracy innymi tezami, że Suárez, mimo deklarowanej akceptacji dla teorii analogii, wydaje się operować jednoznacznym pojęciem bytu jako bytu, a nadto praktycznie wszedł na drogę przekształcania metafizyki w ontologię, skupiając wysiłek poznawczy na wypracowaniu najogólniejszych abstrakcyjnych pojęć dotyczących bytu a potem na ich analizie. Co prawda z zaprezentowanych przez K. Gryżenię rozważań wynika, że element wypracowywania pojęć, właściwy metafizyce, był tutaj obecny, ale znaczny był także udział ich analizy. Nie można jednak wykluczyć, że hiszpański scholastyk stosował w tym przypadku po prostu porządek tłumaczenia ustalonych już w tradycji tez, czyniąc to w celach dydaktycznych.

W wielu miejscach omawianej monografii pojawia się nadto zagadnienie balansowania na granicy analogii i jednoznaczności w określaniu pojęcia bytu jako bytu. Problem ujednoznaczniania go jest wyostrzony we wnioskach do Rozdziału 1 (s. 58-59), a także $w$ prezentacji kwestii odróżniania przez hiszpańskiego jezuitę logicznego i metafizycznego pojęcia bytu (s. 121-129). W obronie F. Suáreza, można przywołać współczesne nam spory logików z metafizykami, a także niemal przesłaniające klasycznie uprawianą filozofię bytu, oparte na najnowszych dokonaniach logiki, dzisiejsze wersje ontologii. Wydaje się bowiem, że mógł on dostrzec rdzeń trudności, która jest źródłem także obecnych nieporozumień. Logika pozbawiona zewnętrznych ograniczeń wydaje się przeprowadzać swe rozważania w całkowitym oderwaniu od struktury rzeczywistości naturalnej. Konsekwentnie nie prowadzi zatem do wniosków zgodnych z tą ostatnią. Uzgodnienie metafizycznego i logicznego pojęcia bytu wydaje się $\mathrm{w}$ tej perspektywie nie do wykonania. Opierając się na ustaleniach K. Gryżeni, należałoby raczej poczytać Suárezowi za zasługę to, że zasygnalizował rozbieżności między tymi dwoma pojęciami bytu.

Poza tym lektura omawianej monografii wskazuje, że sformułowana przez Suáreza koncepcja analogii atrybucji wewnętrznej jest de facto doprecyzowaniem i poprawniejszym ujęciem pomysłu Franciszka Sylwestra z Ferrary i Piotra Fonseki, którzy pod względem koncepcyjnym łączyli niezbornie analogię proporcjonalności i atrybucji zewnętrznej, by wyjaśniać za ich pomocą charakter relacji stworzenia do Stwórcy. Nie do końca przekonuje przy tym argumentacja K. Gryżeni, że przyjęcie analogii atrybucji wewnętrznej jest akceptacją koncepcji jednoznaczności transcendentalnej w rozumieniu bytu jako przedmiotu metafizyki. Należy jednak przyznać, że przez samego Suáreza rzecz nie została dostatecznie jasno opisana, by nie mieć zasadnych 
wątpliwości tak co do analogiczności, jak do jednoznaczności wprowadzonego przezeń pojęcia bytu. Rozstrzygnięcie tej kwestii rzutowałoby oczywiście na ocenę poprawności koncepcji analogii atrybucji wewnętrznej. Opierając się na toku rozważań, należy sądzić, że autor omawianej monografii jest zwolennikiem koncepcji M. A. Krąpca, który wskazywał, jako jedyną mającą zastosowanie w dowodzeniu istnienia Boga, analogię transcendentalną proporcjonalności właściwej (zob. s. 232237). K. Gryżenia dokonał zatem swego rodzaju krytyki zewnętrznej, jak najbardziej wszakże uprawnionej $\mathrm{w}$ badaniach $\mathrm{z}$ zakresu historii filozofii, na co zwracał już swego czasu uwagę É. Gilson.

Wydaje się niemniej, że surowa ocena, którą w ogólnym ujęciu wystawia suarezjańskiej koncepcji bytu i analogii, mogłaby być złagodzona. Na podstawie lektury omawianej pracy można wyrobić sobie przekonanie, że F. Suárez zwrócił uwagę na pewne niedociągnięcia w nauczaniu swoich poprzedników. Mimo wykazanych niejasności i trudności terminologicznych autor monografii dostrzegł w jego doktrynie przecież i liczne, przywołane wyżej, elementy pozytywne. Tymczasem po przeczytaniu końcowych konkluzji można jednak odnieść wrażenie całkowitego odrzucenia omawianych w rozprawie głównych koncepcji suarezjańskich.

Z innych uwag krytycznych, należy wskazać, że tekst monografii zawiera niekiedy niezgrabności stylistyczne (w szczególności na s. 141-142). Wydaje się nawet, że niektóre partie zostały napisane w pośpiechu i nie przeszły należytej korekty. W ogólnym rozrachunku wyrażone tutaj poglądy autora są niewątpliwie doniosłym głosem w dyskusji nad metafizyką F. Suáreza i przełomem, który wniosła tzw. druga scholastyka, wraz z konsekwencjami tego zjawiska dla całej filozofii nowożytnej. Praca jest zaś warta uwagi środowiska badaczy specjalizujących się w dziejach myśli filozoficznej, nie tylko wspomnianego okresu. 